Jurnal Magisma Vol. 7 No. 1 - Tahun 2019 | 35

\title{
DANA DESA DALAM PENINGKATAN KESEJAHTERAAN MASYARAKAT PADA DESA WISATA MENGGORO
}

\author{
Oleh \\ Yulfan Arif Nurohman \\ Dosen IAIN Surakarta \\ yulfan.arif.nurohman@iain-surakarta.ac.id \\ Rina Sari Qurniawati \\ Dosen Tetap STIE AMA Salatiga \\ rinasari.qurniawati@stieama.ac.id \\ Fuad Hasyim \\ Dosen IAIN Surakarta \\ hasyimfuad19@gmail.com
}

\begin{abstract}
ABSTRAK
Wisata menjadi salah satu sektor unggulan yang dikembangkan oleh pemerintah. Keberadaan wisata dianggap sebagai sebuah potensi daerah dalam peningkatan pendapatan. Masyarakat dilibatkan dalam pengelolaan potensi wisata daerah. Pada tahun 2016 Pemerintah Kabupaten Temanggung menetapkan sepuluh desa wisata, salah satunya Desa Menggoro yang terdapat wisata tradisi Jum'at Pahing dan wisata religi Masjid Jami' Menggoro. Pengembangan desa wisata menggunakan dana desa yang diberikan oleh pemerintah. Dana desa yang dikucurkan diharapkan mampu meningkatkan animo masyarakat dalam berkunjung pada desa wisata dengan memperbaiki dan menambah beberapa fasilitas pendukung. Tujuan dari penelitian ini adalah mempelajari pengaruh dana desa dalam meningkatkan kesejahteraan masyarakat. Penelitian ini dilakukan di Desa Menggoro dengan 100 responden. Teknik sampel yang digunakan dalam penelitian ini adalah teknik purposive sampling dan menggunakan alat analisis regresi berganda. Hasil dari penelitian menunjukan bahwa terdapat pengaruh yang positif antara kebijakan desa dengan kesejahteraan masyarakat.

Kata kunci: Dana desa, Kebijakan, Desa wisata, Wisata tradisi Jum'at Pahing, Wisata religi Masjid Jami’ Menggoro
\end{abstract}

\section{PENDAHULUAN}

Sektor wisata merupakan salah satu unggulan program pemerintahan era JokowiJusuf Kalla. Pariwisata diproyeksikan oleh pemerintah akan mengalami pertumbuhan yang pesat dalam menyumbang devisa pada tahun 2019. Tahun 2015 dan 2016, sektor wisata mampu menyumbang devisa sebesar US\$ 12,225 milliar dan US\$ 13,658 milliar.
Devisa mampu memberikan peran yang besar bagi pemerintahan untuk melakukan pembangunan.

Desa Menggoro pada tahun 2016 ditetapkan sebagai salah satu dari sepuluh desa wisata oleh Pemerintah Kabupaten Temanggung. Di Desa Menggoro terdapat wisata tradisi jumat pahing dan wisata religi Masjid Wali dan makam Kiai Pahing. Wisata 
tradisi jumat pahing telah berjalan secara turun-temurun dan terus dilestarikan hingga saat ini. Masjid Jami' Menggoro merupakan salah satu masjid dari Sembilan masjid tertua di Jawa. Masjid ini berdiri saat perkembangan Islam di Jawa. Berdasarkan data Pemerintah Kabupaten Temanggung, Masjid Jami' Menggoro didirikan pada tahun Saka 1786 atau sekitar 1722 Masehi.Keberadaan wisata tradisi dan religi mampu menghadirkan pengunjung untuk datang ke Desa Menggoro.

Wisata religi dan wisata tradisi menjadi salah satu potensi wisata yang digarap serius oleh Pemerintah Daerah Temanggung. Dukungan dari pemerintah daerah diberikan dengan memberikan pendampingan, pelatihan, pembangunan fasilitas dan bantuan promosi wisata. Wisata religi dan tradisi diharapkan mampu mendongkrak pariwisata di Kabupaten Temanggung. Jumlah pengunjung wisata religi Masjid Jami' Menggoro dan tradisi jumat pahing terus mengalami peningkatan. Hal ini tidak lepas karena peran Pemerintah Kabupaten Temanggung dalam mempromosikan potensi wisata di Kabupaten Temanggung.

Pasar Jumat Pahing mengalami renovasi beberapa kali. Perbaikan dilakukan untuk mendukung sarana dan prasarana wisata religi jumat pahing. Perbaikan meliputi pembenahan atap, pembangunan kios, perbaikan alas, perbaikan jalan dan pembangunan toilet. Renovasi pasar jumat pahing menggunakan dana desa yang dijalankan oleh pihak luar sebagai pemenang tender. Adapun jangka waktu renovasi berlangsung selama tiga bulan.

Berdasarkan data Kementerian Keuangan Tahun 2017, Dana Desa terbukti telah menghasilkan sarana/prasarana yang bermanfaat bagi masyarakat. Adapun bukti penggunaan Dana Desa meliputi jalan desa lebih dari 95,2 ribu kilometer; 914 ribu meter jembatan; 22.616 unit sambungan air bersih;
2.201 unit tambatan perahu; 14.957 unit PAUD; 4.004 unit Polindes; 19.485 unit sumur; 3.106 pasar desa; 103.405 unit drainase dan irigasi; 10.964 unit Posyandu; dan 1.338 unit embung dalam periode 20152016.

Dana Desa mampu memberikan kesempatan bagi desa dalam mengembangkan ekonomi masyarakat. Pengembangan tersebut melalui pelatihan dan pemasaran kerajinan masyarakat, pengembangan usaha peternakan dan perikanan, dan pengembangan kawasan wisata melalui BUMDes (badan usaha milik desa). Tujuan mensejahterakan masyarakat dapat dilakukan oleh desa dengan memperhatikan sentuhan inisiasi, inovasi, kreasi dan kerjasama antara aparat desa dengan masyarakat.

Berdasarkan penelitian Dura (2016) menyatakan bahwa akuntabilitas pengelolaan keuangan alokasi dana desa, kebijakan desa, dan kelembagaan desa berpengaruh terhadap kesejahteraan masyarakat.

Guna menjawab pertanyaan diatas maka perlu dilakukan penelitian tentang dana desa dan kebijakan desa dalam peningkatan kesejahteraan pada masyarakat pada Desa Wisata Menggoro.

\section{PAPARAN TEORITIS}

\section{Kesejahteraan Sosial}

Kesejahteraan dipandang sebagai keadaan yang lebih baik. Pengertian dari kesejahteraan sosial adalah sistem yang terorganisir dari institusi dan pelayanan sosial yang dirancang untuk membantu individu atau kelompok untuk mencapai standar hidup dan kesehatan yang lebih baik (Friedlander, 1961). Sedangkan menurut Undang-undang No 11 Tahun 2009, tentang Kesejahteraan Sosial.Kesejahteraan sosial adalah kondisi terpenuhinya kebutuhan material, spiritual, dan sosial warga negara agar dapat hidup layak dan mampu mengembangkan diri, sehingga dapat melaksanakan fungsi sosialnya. 
Berdasarkan Biro Pusat Statistik Indonesia (2000) dalam mengetahui tingkat kesejahteraan rumah tangga dapat menggunakan beberapa indikator sebagai ukuran, diantaranya sebagai berikut:

a. Tingkat pendapatan keluarga

b. Komposisi pengeluaran rumah tangga dengan membandingkan pengeluaran untuk pangan dengan non-pangan

c. Tingkat pendidikan keluarga

d. Tingkat kesehatan keluarga

e. Kondisi perumahan serta fasilitas yang dimiliki dalam rumah tangga

Sedangkan menurut Kolle (1974) dalam Bintarto (1989), kesejahteraan masyarakat dapat diketahui melalui beberapa aspek kehidupan, diantaranya:

a. Kualitas hidup dari segi materi, meliputi keadaan tempat tinggal dan pemenuhan gizi pada pangan

b. Kualitas hidup dari segi fisik, meliputi kesehatan dan keadaan lingkungan sekitar

c. Kualitas hidup dari segi mental, meliputi fasilitas pendidikan

d. Kualitas hidup dari segi spiritual, meliputi moral, etika dan keserasian penyesuaian

\section{Dana Desa}

Berdasarkan Undang-Undang Nomor 6 Tahun 2014 Tentang Dana Desa memberikan peluang bagi desa untuk mengembangkan desa sesuai dengan potensi yang dimiliki. Dana Desa merupakan dana yang dianggarkan setiap tahun dalam APBN yang diberikan kepada setiap desa sebagai salah satu sumber pendapatan desa (Kementerian Keuangan, 2017). Kebijakan ini sekaligus mengintegrasikan dan mengoptimalkan seluruh skema pengalokasian anggaran dari Pemerintah kepada desa. Penggunaan Dana Desa sebagai langkah yang dilakukan oleh pemerintah desa dalam meningkatkan kesejahteraan masyarakat. Sukesi (2007) menyatakan bahwa Alokasi Dana Desa dapat membiayai program Pemerintah Desa dan efektif meningkatkan ekonomi pedesaan.

Kesempatan dan kewenangan Pemerintah Desa dalam melakukan pembangunan diharapkan mampu meningkatkan kesejahteraan masyarakat. Mahfudz (2009) berpendapat bahwa Alokasi Dana Desa berperan penting dalam pembangunan fisik desa. Penggunaan dana desa menjadi tanggung jawab penuh pemerintahan desa.

Tujuan Dana Desa berdasarkan landasan hukum Undang-Undang Nomer 6 Tahun 2104 tentang desa meliputi:

1. Meningkatkan pelayanan publik di desa,

2. Mengentaskan kemiskinan

3. Memajukan perekonomian desa

4. Mengatasi kesenjangan pembangunan antardesa

5. Memperkuat masyarakat desa sebagai subjek dari pembangunan

Penyaluran Dana Desa dilakukan dari APBN kepada Pemerintah Desa. Dana Desa adalah hak pemerintah desa, tetapi dalam penyaluran Dana Desa melibatkan peran dan fungsi Pemerintah kabupaten/kota. Demi mewujudkan prinsip transparansi dan akuntabilitas serta memastikan capaian penggunaan dana desa, proses penyaluran Dana Desa mempersyaratkan beberapa kriteria yang harus dipenuhi terlebih dahulu, baik oleh Pemerintah desa sebagai pengguna dana desa maupun oleh kabupaten/kota. Ketentuan terkait penyaluran dana desa diatur dalam Peraturan Menteri Keuangan No. 50/PMK.07/2017 tentang Pengelolaan Transfer ke Daerah dan Dana Desa, sebagaimana diubah dengan Peraturan Menteri Keuangan No. 112/PMK.07/2017.

Peraturan Bupati Temanggung Temanggung Nomor 11 Tahun 2008 tentang Pedoman Pelaksanaan Alokasi Dana Desa Kabupaten Temanggung Tahun 2008 yang menetapkan bahwa pelaksanaan Alokasi Dana Desa wajib dilaporkan oleh Tim Pelaksana Desa dan mempertanggung 
jawabkan pelaksanaan APBDes sesuai dengan Peraturan Daerah Kabupaten Temanggung Nomor 8 Tahun 2007. Pengawasan pelaksanaan Alokasi Dana Desa secara internal dilaksanakan oleh Kepala Desa, Badan Permusyawaratan Desa, serta masyarakat sebagai bentuk kontrol sosial terhadap pelaksanaan Alokasi Dana Desa.

\section{H1: Dana Desa berpengaruh terhadap kesejahteraan masyarakat Desa Wisata Menggoro}

\section{Kebijakan Desa}

Sebuah kebijakan dibuat pasti berangkat dari sebuah kondisi dimana kebijakan itu harus dibuat. Seperti halnya kebijakan publik, kebijakan publik dibuat dalam rangka menyelesaikan permasalahan yang berkaitan dengan publik. Masalah tersebut begitu banyak macamnya, variasinya dan intensitasnya. Oleh karena itu, tidak semua masalah publik itu bisa melahirkan kebijakan publik. Hanya masalah-masalah yang mampu menggerakkan orang banyak untuk ikut memikirkan dan mencari solusi yang bisa menghasilkan sebuah kebijakan publik.( Widodo, Joko.2007: hal 14) Di bawah ini merupakan beberapa definisi kebijakan publik menurut para ahli.

Kebijakan pemerintah desa merupakan salah satu produk hukum karena setiap pemerintah desa secara hukumpun memiliki wewenang tersebut, meskipun berskala kecil dan lokal yang mencangkup wilayah administrasi desa itu sendiri (Dura, 2016). Sesuai dengan amanat UU No. 6/2014 tentang Desa, tujuan pembangunan desa adalah meningkatkan kesejahteraan masyarakat desa dan kualitas hidup manusia serta penanggulangan kemiskinan melalui pemenuhan kebutuhan dasar, pembangunan sarana dan prasarana desa, membangun potensi ekonomi lokal, serta pemanfaatan sumberdaya alam dan lingkungan secara berkelanjutan. Pembagunan ini harus memiliki ketahanan sosial, ekonomi, dan ekologi serta mendorong keterkaitan desakota.

Menurut Purwanto, Agus, dan Sulistyastuti (2015) kebijakan desa dapat diukur melalui beberapa indikator, diantaranya sebagai berikut:

a. Akses

Pengertian dari akses adalah kesempatan yang sama bagi semua kelompok maupun individu yang meliputi gender, etnisitas dan agama. Akses juga dapat diartikan sebagai peluang yang sama bagi masyarakat dalam menikmati program dan kebijakan.

b. Bias

Pengertian dari bias merupakan penilaian yang digunakan dalam pemanfaatan program atau kebijakan yang diambil tidak terjadi penyimpangan. Pemanfaatan program dan kebijakan berlaku untuk semua, baik individu maupun kelompok.

c. Ketepatan layanan

Indikator ketepatan layanan digunakan dalam mengukur program yang dijalankan oleh pemerintah desa sesuai dengan ketepatan perencanaan dan waktu pelaksanaan.

d. Akuntabilitas

Indikator akuntabilitas digunakan dalam mengukur penggunaan dana desa secara transparan dan dapat dipertanggung jawabkan.

e. Kesesuaian program dan kebutuhan

Indikator ini digunakan dalam mengetahui bahwa program dan kebijakan desa yang dilaksanakan sesuai dengan kebutuhan masyarakat.

H2: Kebijakan desa berpengaruh terhadap terhadap kesejahteraan masyarakat Desa Wisata Menggoro

\section{METODE PENELITIAN}

Tipe penelitian ini adalah tipe penelitian deskriptif yaitu tipe penelitian yang bertujuan untuk memberikan gambaran mengenai subjek penelitian berdasarkan data 
variabel yang diperoleh dari subjek yang diteliti dan dimaksudkan untuk pengujian hipotesis (Azwar, 2000:56). Populasi pada penelitian ini adalah yang terkait langsung dengan Wisata Tradisi Jumat Pahing dan Wisata Religi Masjid Jami' Menggoro. Metode pemilihan sampel (sampling) dalam penelitian ini dilakukan secara non probability dengan teknik purposive sampling. Alasan utama pengambilan sampel dilakukan secara non probability karena keterbatasan waktu, tenaga, dan biaya.

Adapun ukuran sampel yang akan digunakan, ditentukan berdasarkan pada

\begin{tabular}{|l|rl|}
\hline \multicolumn{1}{|c|}{ Variabel } & & \multicolumn{1}{c|}{ Indikator } \\
\hline $\begin{array}{l}\text { Alokasi Dana } \\
\text { Desa }\end{array}$ & i. & Penggunaan dana desa sesuai UU yang berlaku \\
& ii. & $\begin{array}{l}\text { Pembangunan menggunakan dana desa direncanakan, dikelola, dan } \\
\text { dikendalikan oleh pemerintahan desa }\end{array}$ \\
& iii. & Informasi penggunaan dana desa diberikan secara menyeluruh \\
iv. & Pembangunan menggunakan dana desa untuk kepentingan seluruh masyarakat \\
\hline Kebijakan & i. & Tidak terjadi diskriminasi dalam pemanfaatan dana desa \\
& ii. & Penggunaan dana desa tidak manipulatif \\
& iii. & Proses pembangunan tepat waktu \\
& iv. & Kebijakan dana desa dapat dipertanggungjawabkan \\
\hline Kesejahteraan & v. & Penggunaan dana desa tepat sasaran \\
\hline i. & Pendapatan \\
& ii. & Konsumsi dan pengeluaran rumah tangga \\
& iii. & Keadaan tempat tinggal \\
& iv. & Fasilitas tempat tinggal \\
& v. & Kesehatan anggota keluarga \\
& vi. & Kemudahan mendapatkan fasilitas kesehatan \\
& ii. & Kemudahan memasukkan anak ke jenjang pendidikan \\
& iii. & Kemudahan mendapatkan fasilitas transportasi \\
\hline
\end{tabular}

\section{Alat Analisis}

Analisa data dilakukan dengan menggunakan metode analisa kuantitatif yaitu dengan mengumpulkan, mengolah, dan menginterpretasikan data yang diperoleh sehingga memberi keterangan yang benar dan lengkap untuk pemecahan masalah yang dihadapi. Dalam menganalisis data, peneliti menggunakan analisis regresi berganda.
Roscoe (1975) yaitu ukuran sampel sebaiknya 10x lebih besar dari jumlah variabel dalam penelitian. Namun, untuk menghindari resiko adanya unit sampel yang cacat dan tidak dapat diolah, maka ukuran sampel yang direncanakan adalah sebanyak 100 responden.

\section{Definisi Operasional}

Definisi operasional merupakan penjabaran suatu variabel penelitian kedalam indikator-indikator yang lebih terinci sehingga variabel yang ada dapat diukur. Definisi operasional penelitian ini adalah 
validitas dilakukan dengan Confirmatory Factor Analysis (CFA). CFA ini perlu dilakukan karena dapat menguji apakah suatu konsturk mempunyai unindimensionalitas atau apakah indikator-indikator yang digunakan dapat mengkonfirmasi sebuah konstruk atau variabel. Indikator-indikator masing-masing konstruk yang memiliki loading factor yang signifikan menunjukkan bahwa indikator tersebut merupakan suatu kesatuan alat ukur yang mengukur konstruk yang sama dan dapat memprediksi dengan baik konstruk yang seharusnya diprediksi (Hair et al., 1998). Uji validitas dilakukan dengan menggunakan confirmatory factor analysis dengan software SPSS.

Selanjutnya, pengujian reliabilitas setiap konstruk dilakukan dengan menggunakan koefisien Cronbach's . semua variabel yang ada dalam penelitian ini yaitu, electronic word of mouth, pengguna aktif sosial media, pengaruh keluarga, dan pengaruh teman sebaya menunjukkan hasil di atas 0,6. Hal ini mengindikasikan bahwa semua responden menjawab semua pertanyaan dalam kuesioner dengan konsisten.

Tabel 2. Uji Reliabilitas

\begin{tabular}{|c|c|c|c|}
\hline No & Variabel & $\begin{array}{c}\text { Cronbach's } \\
\text { Alpha }\end{array}$ & $\begin{array}{c}\text { Keteranga } \\
\mathbf{n}\end{array}$ \\
\hline 1 & Alokasi Dana Desa (ADD) & 0.703 & Reliabel \\
\hline 2 & Kebijakan Desa & 0.857 & Reliabel \\
\hline 3 & Kesejahteraan Masyarakat & 0.957 & Reliabel \\
\hline
\end{tabular}

Tabel 3. Uji Validitas

\begin{tabular}{|c|c|c|c|}
\hline Variabel & 1 & 2 & 3 \\
\hline Alokasi Dana Desa 1 & & & 0.857 \\
\hline Alokasi Dana Desa 2 & & & 0.501 \\
\hline Alokasi Dana Desa 3 & & & 0.790 \\
\hline Alokasi Dana Desa 4 & & & 0.630 \\
\hline Kebijakan 1 & & 0.945 & \\
\hline Kebijakan 2 & & 0.825 & \\
\hline Kebijakan 3 & & 0.790 & \\
\hline Kebijakan 4 & & 0.675 & \\
\hline Kebijakan 5 & & 0.832 & \\
\hline Kesejahteraan 1 & 0.881 & & \\
\hline Kesejahteraan 2 & 0.790 & & \\
\hline Kesejahteraan 3 & 0.952 & & \\
\hline Kesejahteraan 4 & 0.882 & & \\
\hline Kesejahteraan 5 & 0.931 & & \\
\hline Kesejahteraan 6 & 0.905 & & \\
\hline Kesejahteraan 7 & 0.572 & & \\
\hline Kesejahteraan 8 & & & \\
\hline
\end{tabular}


Uji normalitas pada penelitian ini menunjukkan bahwa pada histogram dan normal probabilitu plotnya memiliki pola berdistribusi normal yang ditandai dengan bentuk grafik yang menyerupai lonceng serta

Tabel 4. Uji Multikolinieritas

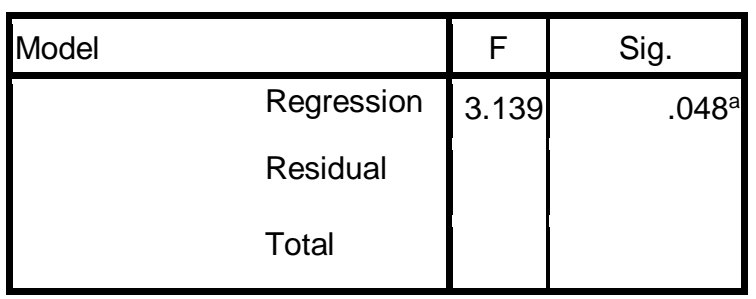

Dependent Variable: Total Kesejahteraan

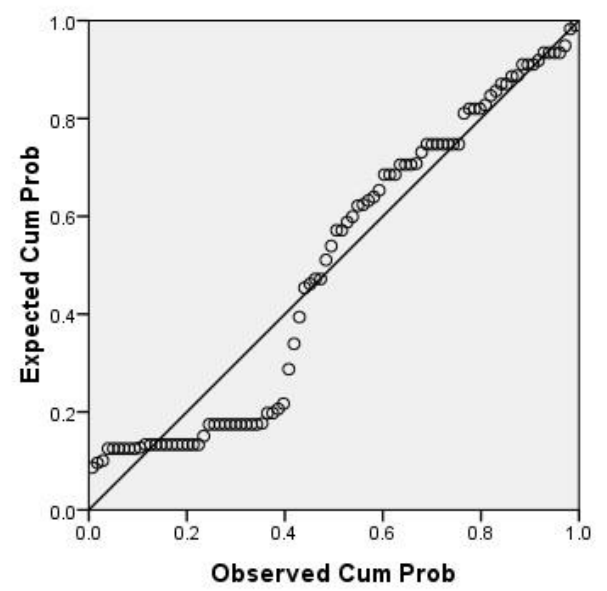

Uji multikolinieritas nilai VIF < 10 yaitu X1 1,822 dan X2 1,822, berarti tidak Tabel 6. Persamaan Regresi Berganda

\begin{tabular}{llll}
\hline Variabel & \multicolumn{1}{l}{$\beta$} & $\mathrm{t}_{\text {nluna }}$ & Sig \\
\hline Konstan & 5.871 & & \\
$\mathrm{X} 1$ & -1.165 & -2.439 & 0,017 \\
$\mathrm{X} 2$ & 0.741 & 2.062 & 0,042 \\
$\mathrm{R}^{2}=$ & 0,257 & & \\
\hline
\end{tabular}

Pada bagian ini model regresi berganda diterapkan untuk menguji variabel independen yaitu pengguna aktif Alokasi Dana Desa dan Kebijakan Desa pada variabel dependen yaitu Kesejahteraan Masyarakat. Pada model regresi berganda ini digunakan SPSS 16 for Windows dan pada regresi menggunakan metode enter. Metode enter adalah metode yang memasukkan semua tepat ditengah sumbu $\mathrm{X}$ dan $\mathrm{Y}$. selain itu juga pada uji kolomogrovsmirnov nilai sig > 0,05 yaitu $0,254>0,05$ berarti residual terdistribusi secara normal. Ditunjukan dalam diagram berikut :

terdapat korelasi antara variable independen dalam model regresi atau tidak terjadi multikolinieritas. Sedangkan uji heteroskedastisitasnya terdapat pola yang jelas dan titik-titik menyebar diatas dan dibawah 0 ada sumbu $Y$ maka dapat disimpulkan bahwa tidak terjadi gangguan heteroskedastisitas pada model regresi.

Tabel 5. Uji T (Anova) variabel independen kedalam persamaan regresi.

Pada analisis regresi berganda diperoleh hasil uji $\mathrm{F}$ dalam table ANOVA nilai probabilitasnya $<0,05$ yaitu $0,048<$ 0,05 berarti terdapat pengaruh yang signifikan secara bersama-sama antara variable alokasi dana desa, kebijakan desa, kelembagaan desa terhadap kesejahteraan masyarakat. Dari pengujian hipotesis 1 diperoleh hasil bahwa terdapat pengaruh negatif antara alokasi dana desa dengan kesejahteraan masyarakat. Dari hasil ini berarti warga desa Menggoro yang bertempat tinggal di daerah wisata religi jumat pahing tidak merasakan dampak langsung dari 
penggunaan dana desa untuk perbaikan fasilitas Wisata Religi Jum'at Paling. Hal ini dikarenakan lebih banyak pendatang dari luar desa yang berjualan di wisata religi Jum'at Pahing dibandingkan dengan warga lokal.

Hipotesis ke 2 diperoleh hasil bahwa terdapat pengaruh yang positif antara kebijakan desa dengan kesejahteraan masyarakat. Hal ini berarti Pemerintah Desa Menggoro sudah berhasil dalam mengidentifikasi potensi dan menentukan arah kebijakan sehingga kesejahteraan masyarakat dapat tercapai. Dengan banyaknya potensi ekonomi yang muncul dari aktivitas Wisata Religi Jum'at Paling, maka dibutuhkan kebijakan dari pemerintah desa yang mampu meningkatkan kesejahteraan masyarakat Desa Menggoro.

\section{SIMPULAN DAN SARAN}

Alokasi Dana Desa dan kebijakaan di Desa Menggoro secara normatif dan administratif sudah berjalan dengan baik. Namun, secara subtantif penggunaan dana desa untuk memperbaiki fasilitas Wisata Religi Jum'at Paling belum dirasakan dampaknya oleh warga setempat. Hal ini dikarenakan kegiatan jual beli yang dilakukan dalam kegiatan tersebut masih didominasi oleh warga di luar Desa Menggoro. Hal ini berarti warga setempat tidak merasakan dampak langsung dengan adanya alokasi dana desa untuk perbaikan Wisata Religi Jum'at Paling. Kebijakan yang harus dibuat oleh pemerintah adalah mendorong warga setempat untuk lebih berperan aktif dalam kegiatan penjualan di Wisata Religi Jum' at Paling, agar tidak hanya warga luar yang memperoleh manfaat secara ekonomi akan tetapi sebagian besar warga setempat juga merasakan dampaknya. Selain itu, Pemerintah desa harus mampu mendorong tingkat partisipasi masyarakat yaitu dengan membuka ruang bagi masyarakat untuk turut mengambil bagian didalamnya. Hal tersebut bisa dilakukan dengan membuka forum-forum dialog antara pemerintah desa dengan masyarakat yang mengangkat tentang isu dana desa bagi peningkatan perekonomian warga setempat dengan adanya kegiatan di Wisata Religi Jum'at Paling

Keterbatasan dalam penelitian ini hanya menggunakan data dari responden yang berkecimpung langsung di Wisata Religi Jum'at Paling. Maka saran untuk peneliti selanjutnya dengan menambah responden dengan melibatkan semua warga Desa Menggoro agar lebih akurat dalam meneliti terutama mengenai kesejahteraan masyarakat. Selain itu, untuk penelitian selanjutnya diharapkan untuk menambah variabel penelitian seperti kelembagaan desa dan pemberdayaan masyarakat sehingga hasil penelitian tentang kesejahteraan masyarakat menjadi lebih komprehensif. 


\section{Daftar Pustaka}

Azwar, Saifuddin. 2000. Reabilitas dan Validitas. Yogyakarta :Pustaka Belajar:.

Bintarto. 1989. Interaksi Desa Kota dan Permasalahannya. Jakarta: Penerbit Ghalia Indonesia.

Dr. Widodo, Joko.2007. Analisis Kebijakan Publik: Konsep dan Aplikasi Analisis Proses Kebijakan Publik

Dura, Justita, 2016. Pengaruh Akuntabilitas Pengelolaan Keuangan Alokasi Dana Desa, Kebijakan Desa, Dan Kelembagaan Desa Terhadap Kesejahteraan Masyarakat (Studi Kasus Pada Desa Gubugklakah Kecamatan Poncokusumo Kabupaten Malang). Jurnal JIBEKA . Volume 10 Nomor 1 Agustus 2016: 26 - 32

Friedlander, Walter. 1961. Pengantar Kesejahteraan Sosial. Jakarta: Gema Insani Press.

Hair et al.. 1998. Multivariate Data Analysis, Fifth Edition, New Jersey: Prentice Hall, Upper Saddle River.:

Mahfudz, 2009. Analisis Dampak Alokasi Dana Desa (ADD) Terhadap Pemberdayaan Masyarakat dan Kelembagaan Desa. Diakses dari http://jurnal.ut.ac.id/index.php/JOM/ article/download/22/12/ pada tanggal 30 September 2018

Purwanto, agus, erwan dan Sulistyastuti, Dyah Ratih.2015. Implementasi kebijakan Publik. Konsep dan Aplikasinya di Indonesia. Yogyakarta.: Gava Media.

Roscoe, J. T., 1975, Fundamental Research Statistics for the Behavioral Sciences. New York: Holt, Rinehart and Winston, Inc.

Sukesi, [2007], Efektivitas Program alokasi dana desa ( ADD ) terhadap perekonomian desa di kabupaten Pacitan 